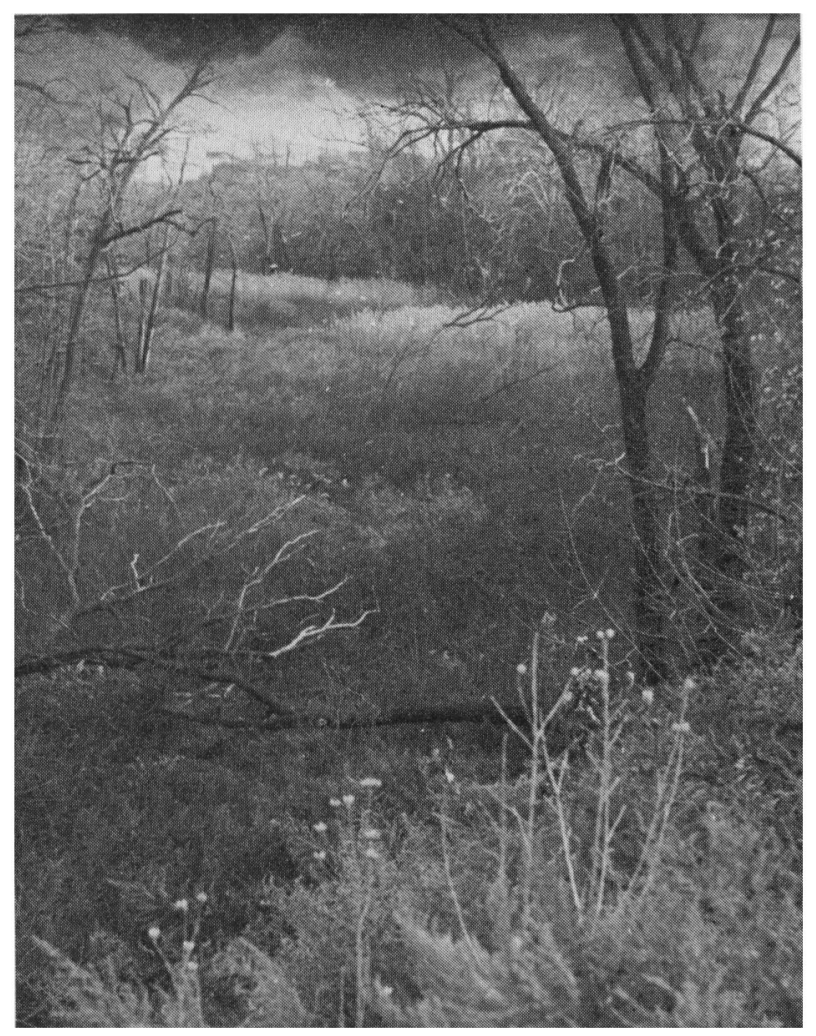

Fig. 2. Looking south at marshland at the base of the ravine where the stream once ran. Note Phragmites and fallen trees-dead due to fill and silting.

Considering the historical and ornithological and other scientific aspects of Oakland Lake and Ravine, steps must be taken to restore the native vegetation, remove the landfill where possible, minimize human impact, make further studies of the area, and enact legislation immediately to ensure protection and survival of such natural areas within New York City as remain (Greller, 1975). Let us hope this will be the future for Oakland Lake and Ravine -the attractive tiny 'wilderness' in the city.

\section{Acknowledgements}

The author wishes to thank Andrew Greller, Samuel Yeaton, James Pion, and Joseph Brown, for information

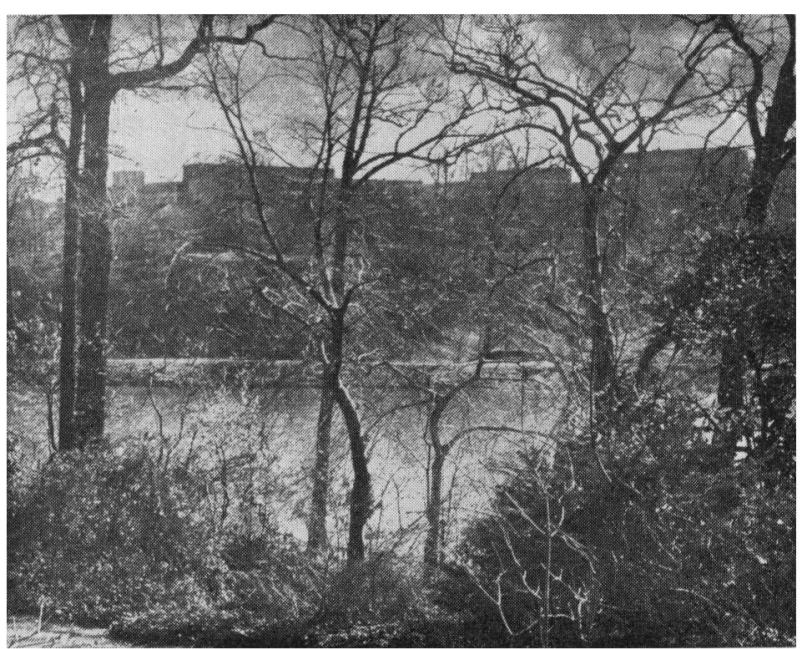

FIG. 3. Taken from a backyard bordering the ravine and looking south. Lake, path, wooded slope, and Queensborough Community College (from bottom to top). Slope is indicative of topography of the area.

that has been included in this article; also Thomas F. Schweitzer and Henry Euler for guidance. The en thusiastic encouragement of Nicholas Polunin, following his visit of November 1974, was particularly appreciated as confirming the sound basis of our cause.

\section{References}

Arbib, Robert S., Jr, Pettringill, Olin S., Jr, \& Spofford, Sally (1966). Enjoying Birds Around New York City. Houghton Mifflin, Boston: 171 pp., illustr.

Greller, Andrew M. (1972). Observations on the forests of northern Queens County, Long Island, from colonial times to the present. Bull. Torrey Bot. Club, 99, pp. 202-6.

Greller, Andrew M. (1975). Persisting natural vegetation in Northern Queens County, New York, with proposals for its conservation. Environmental Conservation, 2(1), pp. 61-9, 6 figs.

\author{
Aline Euler \\ Oakland Lake \\ and Ravine Conservation Committee \\ 220-10 46th Avenue \\ Bayside \\ New York 11361 \\ U.S.A.
}

\title{
World Wildlife Fund Advances
}

The World Wildlife Fund provided over two million dollars (U.S.) for conservation projects all over the world during 1974, according to preliminary figures recently issued. The grants which they made included $\$ 1,613,021$ for 75 international projects ranging from tiger conservation in India to an 'East African Youth Course in Environmental Conservation', and from captive breeding of birds of prey at Cornell University, Ithaca, N.Y., to the establishment of guidelines for the future of the Alps. In addition, national chapters of the Fund paid out grants totalling $\$ 409,416$ to 47 projects within their own countries, including support of nature reserves and projects for the conservation of endangered species.
The year 1974 brought the World Wildlife Funds' total grants since its foundation in 1961 to $\$ 15,092,677$ dollars. With headquarters at Morges, on the northern shore of Lake Geneva, Switzerland, WWF now has 24 National Appeals raising money for, and promoting the cause of, nature conservation. Grants are allocated with the advice of the International Union for Conservation of Nature and Natural Resources (IUCN), the leading international scientific conservation organization.

PETER F.R. JACKSON, Director of Information World Wildlife Fund

1110 Morges

Switzerland. 